\title{
ДОСВІД ПІДГОТОВКИ ІНОЗЕМНИХ ГРОМАДЯН $З$ АНГЛОМОВНОЮ ФОРМОЮ НАВЧАННЯ
}

\author{
І. Г. Савка, С. Д. Савка, С. В. Юрнюк \\ Вищий державний навчальний заклад Украӥни \\ “Буковинський державний медичний університет”, м. Чернівці
}

\section{THE EXPERIENCE OF TRAINING FOREIGN CITIZENS WITH ENGLISH AS A LANGUAGE OF INSTRUCTION}

\author{
I. H. Savka, S. D. Savka, S. V. Yurniuk \\ Bukovynian State Medical University, Chernivtsi
}

\begin{abstract}
У статті висвітлено особливості підготовки іноземних студентів з англомовною формою навчання на додипломному етапі у ВДНЗ України “Буковинський державний медичний університет”. Розкриті основні інструменти контролю за процесами набуття знань, опанування основних навичок та вмінь, ходом підготовки до ліцензійних інтегрованих іспитів "Krok 1, 2. Medicine” та іспитів для підтвердження дипломів на батьківщині випускників. Показана роль цього виду підготовки фахівців як одного 3 перспективних напрямків діяльності вищого навчального закладу. Окреслені перспективи подальших розвідок у вказаному напрямку.
\end{abstract}

The article deals with the peculiarities of training foreign students with English as a language of instruction during pregraduation years at Higher State Educational Establishment of Ukraine "Bukovynian State Medical University". The main instruments of supervision over the processes of mastering knowledge, major skills and abilities in the course of preparing to the licensed integrated examinations "KROK 1, 2. Medicine", and passing the examinations to verify diplomas in the native lands of graduates have been presented. The role of this kind of training specialists is indicated as one of the most perspective directions in the activity of the higher educational establishment. The prospects of further search in this direction are outlined.

Вступ. Підготовка спеціалістів із числа іноземних громадян є важливим і престижним напрямком діяльності вищого навчального закладу. Окрім того, англомовне навчання $є$ важливим фактором стимулювання якості освіти та міжнародних контактів, забезпечує збільшення обсягу фінансових надходжень до університетів, сприяє підвищенню фахового рівня викладачів та інтеграції навчального процесу в міжнародний освітній простір $[1,2]$.

Щорічно майже 70 тисяч іноземних студентів, які навчаються в Україні, вкладають в економіку нашої держави 504 млн дол., що еквівалентно 11 млрд грн і складає майже повну суму фінансування державної форми вищої освіти в Україні.

Навчання іноземних громадян - це не тільки додаткове джерело асигнувань держави, краю, але й важливий чинник зміцнення авторитету, престижу університету та країни в цілому і кожного регіону окремо.

На сьогодні у багатьох вишах України створені факультети, на яких здійснюється підготовка іно(ㄱ І. Г. Савка, С. Д. Савка, С. В. Юрнюк земних громадян, у тому числі й за напрямком “Медицина”. На переважній більшості з них навчання здійснюється англійською мовою, що сприяє більшому припливу іноземних громадян до освітніх закладів нашої країни. Із року в рік зростають також і вимоги до якості підготовки фахівців із числа іноземних громадян та до осіб викладацького складу, які її забезпечують.

На актуальність вказаного напрямку вказує і всезростаюча кількість публікацій, в яких висвітлюються різні аспекти викладання навчальних дисциплін іноземним студентам англійською мовою [3, 4].

У 2011 році з метою оптимізації навчального процесу студентів-іноземців у Буковинському державному медичному університеті був створений медичний факультет № 3, на якому здійснюється підготовка іноземних громадян за спеціальностями “Лікувальна справа” та “Педіатрія”.

Основна частина. Основним завданням нашої роботи є висвітлення досвіду підготовки спеціалістів із числа іноземних громадян у ВДНЗ України “Буковинський державний медичний університет”. 
Розширення міжнародних зв'язків Буковинського державного медичного університету, популяризація сучасних технологій навчання, участь іноземних студентів університету в багатьох міжнародних проектах та науково-практичних конференціях, високий рівень знань та вмінь, що демонструють випускники нашого ВДНЗ після повернення з навчання у своїх країнах, - привели до суттєвого збільшення кількості громадян іноземних країн, які виявляють бажання здобувати вищу медичну освіту в нашому закладі. Так, у даний час на медичному факультеті № 3 (на якому здійснюється підготовка основної частини іноземних громадян в університеті) навчається 1300 іноземних студентів вихідців із понад 35 країн світу. Це втричі більше, ніж у 2011 році, на момент створення факультету.

Навчання на факультеті на всіх 6-ти курсах здійснюється англійською мовою співробітниками університету, які мають значний досвід практичної та викладацької роботи. Слід зазначити, що за останні роки кількість таких фахівців значно зросла і в даний час складає 235 осіб, що становить 41 \% від усього штату науково-педагогічного персоналу університету, а 76 осіб - складають кадровий резерв англомовних викладачів.

Уже традиційно підготовка іноземних громадян на факультеті здійснюється із використанням класичних засобів навчання у поєднанні з досягненнями сучасних передових технологій.

3 останніх впроваджень необхідно відмітити активне використання середовища дистанційного навчання MOODLE для набуття знань, опанування основних навичок та вмінь, контролю за ходом підготовки до ліцензійних інтегрованих іспитів "Krok 1, 2. Medicine”, функціонування модуля підготовки до іспиту МСI для підтвердження дипломів на батьківщині випускників (зокрема в Індії), впровадження на факультеті з минулого навчального року системи “Електронний журнал”.

Перелічені інновації призвели до суттєвого зростання якості підготовки іноземних громадян в університеті.

Так, за останні три роки серед іноземних студентів на медичному факультеті № 3 налічується 5 переможців II етапу Всеукраїнських студентських олімпіад. Студенти факультету демонструють ви-

\section{Список літератури}

1. Англомовне навчання як стимулятор якості освіти та міжнародних контактів / В. М. Запорожан, В. Й. Кре- сокі показники за результатами ЛІІ “Krok 1. Medicine”, посідаючи I-III рейтингові місця серед всіх ВМНЗ України, майже 100 \% випускників факультету успішно складають ЛІІ “Krok 2. Medicine” та проходять підсумкову державну атестацію.

Серед найбільш чисельної спільноти іноземних громадян факультету - вихідців з Індії 43-53 \% випускників 2012-2015 років із першої спроби складають іспит MCI та підтверджують дипломи на своїй батьківщині, отримуючи таким чином право займатися подальшою медичною діяльністю. Це вдвічі більше за випускників, які повернулися після навчання до Індії з інших країн.

За увесь час навчання іноземних громадян в нашому університеті було підготовлено більше як 700 лікарів із понад 60 країн світу.

Наведені здобутки позитивно висвітлюють систему підготовки іноземних громадян у ВДНЗ України “Буковинський державний медичний університет” на арені міжнародної медичної освіти, сприяють залученню ширшого кола іноземців на навчання з багатьох зарубіжних країн, підвищують імідж нашого закладу серед інших провідних університетів близького й далекого зарубіжжя, сприяють розвитку і зміцненню системи вищої медичної освіти у нашій державі.

Висновки. Підготовка спеціалістів із числа іноземних громадян багатьох зарубіжних країн з англомовною формою навчання $є$ перспективним напрямком діяльності ВДНЗ України “Буковинський державний медичний університет”, який в умовах сьогодення забезпечує високий статус навчальному закладу, сприяє підвищенню якості освіти, розширенню міжнародних контактів, підвищенню фахового рівня викладачів та інтеграції навчального процесу в міжнародний освітній простір.

Перспективними у плані наступних розвідок у даному напрямку слід вважати подальше розширення географії іноземців, які виявляють бажання здобувати вищу медичну освіту в нашій державі, підвищення кваліфікації осіб викладацького складу, які забезпечують викладання навчальних дисциплін англійською мовою з отриманням міжнародних сертифікатів відповідного рівня володіння іноземною мовою, розширення набору інструментів навчання та контролю знань із використанням сучасних передових технологій.

сюн, М. Л. Аряєв, О. В. Чернецька // Медична освіта. - 2011. - № 2. - C. 45-47. 
2. Європейська кредитна трансферно-накопичувальна система в контексті реформування англомовного навчання іноземних студентів у Львівському національному медичному універстеті імені Данила Галицького / Б. С. Зіменковський, М. Р. Гжегоцький, Є. С. Варивода [та ін.] // Медична освіта. - 2016. - № 2 . С. 110-112.
3. Досвід роботи щодо підвищення якості підготовки іноземних студентів / Г. В. Дзяк, Т. О. Перцева, Л. Ю. Науменко, Г. В. Горбунова // Медична освіта. 2014. - № 2. - С. 59-61.

4. Аспекти навчання англомовних студентів на кафедрі функціональної діагностики та клінічної патофізіології / С. В. Дзига, М. І. Марущак, О. В. Бакалець [та ін.] // Медична освіта. - 2016. - № 1. - С. 66-67. 